\title{
Úroveň rychlostních schopností děvčat šestých tř́íd na základní škole s rozšířenou výukou tělesné výchovy
}

\section{The speed abilities level of the sixth class girl students of an elementary school with extended teaching of physical education}

\author{
Roman Vala ${ }^{1}$, Marie Valová ${ }^{1}$, Martina Litschmannová ${ }^{2}$ \\ ${ }^{1}$ Pedagogická fakulta Ostravské univerzity, Ostrava \\ ${ }^{2}$ Vysoká škola báňská-Technická univerzita Ostrava
}

\begin{abstract}
Abstrakt
Motorické testy jsou zdrojem di̊ležitých informací potřebných pro řizení tělovýchovného a tréninkového procesu a jsou široce využívány v tělovýchovném výzkumu, tělovýchovné praxi a také při výběru sportovních talentů. V předloženém př́ispěvku chtějí autoři seznámit odbornou veřejnost, trenéry a učitele s úrovní rychlostnich schopností divek 6. tříd ZŠs rozšírenou tělesnou výchovou. Celkem byly v letech 2000-2009 testovány 104 dívky ZŠ. Ke statistickému zpracování získaných výsledků v testu sprint na $50 \mathrm{~m}$ byla použita jednofaktorová ANOVA, na jejiž základě mužeme konstatovat, že v období 2000-2009 došlo ke statistický významným rozdílům $v$ úrovni rychlostních schopností, které mají velký význam nejen pro atletické disciplíny, ale jsou důležité i pro dalši sportovní odvětví. Naše výsledky mohou také sloužit k porovnání výkonnosti divek šestých tříd podobně (sportovně) zaměřených základních škol v testu rychlostních schopností (sprint na 50 metrů).
\end{abstract}

\begin{abstract}
This report sums up the results of our research, carried out between the years 2000 and 2009, into the sprinting abilities of year six female students undergoing additional physical education classes. Test results of motor skills are an important source of information which can be further used in structuring the process of physical education and sports training. Moreover, such tests can be widely used in physical education research, in physical training practice and as a means of selecting students gifted at sports. In total, 104 female secondary school students were tested. In brief, it is possible to conclude that throughout the period of our research, these year six female students had statistically significant differences sprinting abilities. This is an important finding for trainers and teachers as sprinting ability has a great impact not only on other athletic disciplines but also plays a role in other fields of sport. Our research results can be compared to those of other year six students of similarly specialized schools in tests of sprinting abilities (50 metres sprint).
\end{abstract}

Klícová slova: $\quad$ motorické testy, talentovaná mládež, sprint

Key words: $\quad$ motoric tests, talented youth, sprint

Studie vznikla za podpory grantu Ostravské univerzity v Ostravě č. 1610-IGS PdF 3/2009.

\section{Úvod}

Mnohé sportovní výkony charakterizuje z fyzikálního pohledu vysoká, až maximální rychlost pohybu. Rychlostní schopnosti patří v mnoha sportech k důležitým faktorům výkonu. Podmínky jejich projevu mohou být jak standardní (sprinty, skoky), tak proměnlivé (sportovní hry, úpolové sporty). V některých případech mají rozhodující význam ve struktuře výkonu, jindy jen podíl doplňující. Vyšší uplatňování rychlostních schopností v mnoha specializacích je charakteristickým znakem vývojových tendencí současného sportu (Dovalil et al. 2009). Rychlostní schopnosti jsou charakterizovány jako schopnosti uskutečnit pohybový akt v čase co nejkratším. Obecně se uvádí, že člověk, který je rychlý ( $\mathrm{v}$ daném ohledu schopný), by podle definic měl v relativně krátkém čase zahájit pohyb na daný pod- 
nět, zvolený pohybový akt uskutečnit a vykonávat pohyby s vysokou frekvencí (Měkota; Blahuš 1983). Rychlostní schopnosti jsou tedy komplex pohybových schopností provádět krátkodobou pohybovou činnost maximálně do 15 až 20 sekund v daných podmínkách co nejrychleji (Dovalil et al. 2008). Oblast rychlostních schopností je nejméně generalizovanou oblastí pohybových schopností a potvrzuje se u nich výrazný podíl genetické podmíněnosti (Ružbarská; Turek 2007). Jejich genetická podmíněnost je dána asi z 65-80\% (Vindušková et al. 2003), dle Periče (2006) až z $90 \%$. Rychlostní schopnosti patří k pohybovým projevům, které je vhodné rozvíjet co nejdříve. Tento požadavek vychází ze zákonitosti vývoje centrální nervové soustavy, která má pro rychlost význam především z hlediska požadavků na stř́ídání vzruchů a útlumů, především v komplexu nervy-svalová vlákna (Perič 2004). Rychlostní schopnosti jsou z hlediska svého rozvoje nejvíce limitovány relativně krátkým senzitivním obdobím (Dovalil 2002, Perič 2006), a právě v tomto období se s velkou pravděpodobností dají určit jedinci s nadáním pro danou sportovní disciplínu.

Probíhající změny $\mathrm{v}$ transformaci současného školství směřují $\mathrm{k}$ humánním hodnotám $\mathrm{v}$ př́ípravě dětí a mládeže. Ekonomika společnosti závisí především na rozvoji talentovaných a nadaných jedinců. Pohybově talentovaná mládež vyžaduje specifickou péči (Ryba; Dlouhý 2007), a proto je potřeba tuto péči o talentovanou mládež dále rozvíjet. Tato péče se realizuje v rámci sportovní př́pravy ve sportovních klubech a ve školách, které se ve svých školních vzdělávacích programech zaměřují na rozšířenou výuku tělesné výchovy. Dle Dovalila (2009) chápeme talent jako komplex předpokladů pokrývající požadavky kladené na sportovce, který má dosáhnout vysoké sportovní výkonnosti. Jednotlivec se $\mathrm{k}$ těmto požadavkům více či méně blíží, a podle toho hovoříme o míře talentovanosti. Jelikož sportovní příprava je dlouhodobý proces, ve kterém se základy pozdější výkonnosti vytvářejí již ve věku, kdy dítě chodí do školy, je vhodné, aby talentovanost jednotlivce byla rozpoznána co nejdříve. Na druhou stranu právě požadavek co nejvčasnějšího posouzení možné perspektivy sportovce klade nároky na diagnostické prostředky, kvalitu hodnocení a minimalizaci chybných predikcí (Perič 2006). Mnohé odborné studie zabývající se vyhledáváním a rozvojem talentů vyzdvihují nadání a talent jako velmi cenný zdroj pro společnost (Bailey et al. 2004, Bailey; Morley 2006, Hutton; Twist 2006). Význam a důležitost talentovaných jedinců nemůže být podceňována, a proto možná nepřekvapí, že vyhledávání a rozvoj talentů se dostává do popředí zájmu nejen trenérů, učitelů, ale také výzkumných pracovníků zabývajících se pedagogikou sportu (Tranckle; Cushion 2006, Peternelj et al. 2009).

Školní tělesná výchova patř́i k nejrozšiřenějším formám organizované tělovýchovné a sportovní činnosti. Lze říci, že pro mnoho lidí je školní tělocvik prvním dominantním setkáním se záměrnou pohybovou aktivitou. Bohužel pro mnohé z nich zůstává jediným aktivně sportovním pohybem v průběhu života (Rychtecký; Fialová 1998).

Úroveň sportující mládeže a také pohybová úroveň dětí prošla významnými změnami a vývojem, na které je nutné reagovat novými výzkumy. Důležité se jeví aktualizovat známé informace a dále je prohlubovat a doplňovat o nové aspekty (Brodáni; Vrábcová 2006). Problematikou úrovně a rozvoje rychlostních schopností u dětí a mládeže se zabývá množství autorů jak v České republice (Perič 2006, Ryba; Dlouhý 2007, Valová; Vala 2009, Vindušková; Krátký 2001 a další), tak i ve světě (Alricsson et al. 2001, Buková; Gajdošová 2008, Brodáni 2002, Brodáni 2003, Chovanová 2009, Moravec; Šelingerová 1990, Peternelj et al. 2009, Rubická; Lenková 1999, Volver et al. 2005).

Mění se životní styl dětí, které dávají přednost méně náročným aktivitám jako jsou hra na počítači nebo sledování televize. Ryba a Dlouhý (2007) hodnotili 21 volnočasových aktivit pohybově talentované mládeže, kdy byl významně doložen největši zájem o poslech hudby, o hru na hudební nástroj a sledování videa. Přitom je známé, že až okolo $70 \%$ mladých lidí se nevěnuje žádnému sportu a $50 \%$ se nevěnuje žádné mimoškolní zájmové aktivitě (Pajtinka 2007). Klasické výběry dětí do dřivějších sportovních tříd (dnes tříd s rozšířenou tělesnou výchovou) v pravém slova smyslu, tedy diagnostikovat, a vybrat jen ty děti, které projevují určitou míru nadání (talentu), jsou v dnešní době většinou nahrazeny spíše náborem dětí, které mají zájem sportovat. Jedním z možných důvodů, ke kterému je třeba přihlédnout, může být také počet narozených dětí v ČR za dané období, což přehledně dokazuje dlouhodobá křivka porodnosti v ČR. Jen v roce 1995 se narodilo o 35 tisíc dětí méně než v roce 1990 (Český statistický úřad, www. 
Úroveň rychlostních schopností děvčat šestých tříd na základní škole s rozšîrenou výukou tělesné výchovy

czso.cz, 2010). Navíc vedle atletiky existují také další lákavá sportovní odvětví, která mohou být v dnešní době pro děti atraktivnější.

$\mathrm{Z}$ tohoto důvodu probíhá každý rok u všech dětí přijatých do třídy s rozšířenou výukou tělesné výchovy se zaměřením na atletiku diagnostika, která charakterizuje jejich vstupní pohybové schopnosti. Toto testování se provádí v rámci dlouhodobého testování všeobecné kondiční připravenosti. Součástí testové baterie všeobecné kondiční připravenosti, kterou uvádí také Perič (2006), je sprint na 50 metrů, který slouží k testování rychlostních schopností.

\section{Cíl a hypotéza}

Cílem práce bylo diagnostikovat úroveň rychlostních schopností děvčat 6 . tříd na vybrané ZŠ s rozšířenou tělesnou výchovou se zaměřením na atletiku (v letech 2000 až 2009). Otázkou je, zda se současným životním stylem dětí, klesajícím počtem narozených dětí ve sledovaném období a sníženým počtem zájemců o atletiku klesá také úroveň schopností dívek, které byly přijaty do sportovní atletické třídy (tř́ídy s rozšířenou výukou tělesné výchovy). Na základě výše uvedených faktorů ověřujeme hypotézu, že během námi sledovaného období dojde k poklesu střední hodnoty času v testu sprint na 50 metrů.

\section{Metodika}

Testování rychlostních schopností bylo prováděno dle standardizovaného testu T. 76.0 (Měkota; Blahuš 1983). Celkově bylo v průběhu námi sledovaného období 2000-2009 testováno 104 žáků (dívek) šestých tříd s průměrnou výškou 157,1 $\pm 6,04$ centimetrů a váhou 43,4 $\pm 7,57$ kilogramů. Celá tato perioda byla pro statistické zpracování dále rozdělena na tři období: období 1 (2000-2003, 44 dívek), období 2 (2004-2006, 30 dívek) a poslední období 3, které tvořily roky 2007-2009 (30 dívek). Pro popis úrovně zjištěných dat $\mathrm{v}$ jednotlivých obdobích byly užity základní popisné charakteristiky - aritmetický průměr, směrodatná odchylka, minimum, maximum a také $95 \%$ interval spolehlivosti pro určení střední hodnoty. Pro porovnání stř̌edních časů v testu sprint na $50 \mathrm{~m}$ ve zmíněných obdobích byl použit test známý pod názvem Jednofaktorová ANOVA. Ke statistickému zpracování získaných výsledků byl použit statistický program PASW Statistics 18.

\section{Výsledky}

Základní popisná statistika charakterizující časy ve sprintu zjištěné v jednotlivých obdobích jsou uvedeny $\mathrm{v}$ Tabulce 1 . Jak již bylo zmíněno v metodice, byly výsledky testování rychlostních schopností všech 104 žáků (dívek) rozděleny do 3 období a celkově byl vypočten čas v testu sprint na 50 metrů $(8,06$ $\pm 0,49)$ sekund. Sloupec $\mathrm{N}$ udává počty chlapců testovaných v jednotlivých obdobích. V následujícím sloupci lze najít průměrné časy zjištěné v jednotlivých obdobích včetně již zmíněné hodnoty pro celkové období 2000 až 2009 . K těmto hodnotám lze velmi snadno doplnit také př́islušné směrodatné odchylky. Následuje 95\% interval spolehlivosti pro střední hodnotu, který je určen dolní a horní mezí. V tomto intervalu lze s pravděpodobností $95 \%$ očekávat průměrný čas ve sprintu u všech dívek z 6 . tříd obdobně zaměřených škol. Poslední dva sloupce (Minimum a Maximum) udávají nejlepší a nejhorší časy zjištěné v př́slušných obdobích.

Tabulka 1. Popisná statistika testu sprint na 50 metrů (s)

\begin{tabular}{|c|c|c|c|c|c|c|c|}
\hline & \multirow{2}{*}{$\mathrm{N}$} & \multirow{2}{*}{ Průměr } & \multirow{2}{*}{$\begin{array}{c}\text { Směr. } \\
\text { odchylka }\end{array}$} & & \multicolumn{9}{|c|}{$95 \%$ interval spolehlivosti pro průměr } & \multirow{2}{*}{ Minimum } & \multirow{2}{*}{ Maximum } \\
\cline { 5 - 6 } & & & Dolní mez & Horní mez & & 7,5 & 9,0 \\
\hline $2000-2003$ & 44 & 8,18 &, 35 & 8,07 & 8,29 & 7,2 & 9,3 \\
\hline $2004-2006$ & 30 & 8,08 &, 57 & 7,87 & 8,30 & 6,8 & 9,1 \\
\hline Celkem & 104 & 8,06 &, 49 & 7,96 & 8,06 & 6,8 & 9,3 \\
\hline
\end{tabular}


V prvním období (2000-2003) byl vypočten čas $(8,18 \pm 0,35)$ sekund, ve druhém období (2004-2006) byl průměrný čas $(8,08 \pm 0,57)$ sekund. V posledním období (2007-2009) byl vypočten nejlepší průměrný střední čas testu $(7,86 \pm 0,49)$ sekund. V roce 2007 bylo navíc dosaženo nejlepšího výsledku ve sprintu dívek a to času 6,8 sekund. S 95\% spolehlivostí lze předpokládat, že průměrný čas dětí (dívek) nastoupivších do 6. tříd v období 2000-2009 do obdobných typů tříd (škol) se pohyboval v intervalu 7,96-8,16 sekund (viz Tabulka 1).

Tabulka 2. Test normality

\begin{tabular}{|c|c|c|c|c|}
\hline \multirow{2}{*}{ Období } & \multicolumn{3}{|c|}{ Shapiro-Wilk } \\
\cline { 3 - 5 } & & & & p-value \\
\hline \multirow{3}{*}{ Sprint $50 \mathrm{~m}(\mathrm{~s})$} & $2000-2003$ &, 976 & 44 &, 471 \\
\cline { 2 - 5 } & $2004-2006$ &, 939 & 30 &, 088 \\
\cline { 2 - 5 } & $2007-2009$ &, 989 & 30 &, 984 \\
\hline
\end{tabular}

Pro porovnání středních časů ve sprintu na 50 m v obdobích 2000-2003, 2004-2006 a 2007-2009 byl použit test známý pod názvem Jednofaktorová ANOVA. Předpoklady pro použití tohoto testu jsou normalita dat (časů) v každém ze sledovaných období a jejich homoskedasticita (shoda rozptylů). Pro ověrení normality byl použit Shapiro-Wilk test. Jak je zřejmé z Tabulky 2, předpoklad normality nebyl na hladině významnosti $5 \%$ zamítnut pro žádné ze sledovaných období (p-value >0,05), mủžeme jej tedy považovat za splněný.

Tabulka 3. ANOVA

\begin{tabular}{|c|c|c|c|c|c|}
\hline & Součet čtverců & $\begin{array}{c}\text { Stupně } \\
\text { volnosti }\end{array}$ & Prům. čtverec & F & p-hodnota \\
\hline Mezi skupinami & 1,842 & 2 &, 921 & 3,931 &, 023 \\
\hline Uvnitř skupin & 23,665 & 101 &, 234 & & \\
\hline Celkem & 25,507 & 103 & & & \\
\hline
\end{tabular}

Rovněž předpoklad homoskedasticity lze na základě výsledku Leveneho testu ( $\mathrm{p}$-value $=0,058$ ) považovat na hladině významnosti $5 \%$ za splněný. Předpoklady Jednofaktorové ANOVY byly splněny, pro vyhodnocení závislosti shody středních časů ve sprintu na $50 \mathrm{~m}$ na období proto můžeme použít její parametrickou podobu - F-test. Nulová hypotéza byla zamítnuta na základě výsledků ANOVY (Tabulka 3, p-value =0,023). Můžeme tedy konstatovat, že v průběhu námi sledovaných let dochází ke statisticky významné změně střední hodnoty rychlosti u dívek šestých tříd ve sprintu na $50 \mathrm{~m}$ (na hladině významnosti $5 \%$ ).

Po provedení Post Hoc analýzy Bonferroniho metodou byl indikován statisticky významný rozdíl mezi prvním (2000-2003) a třetím (2007-2009) obdobím, což umožňuje interpretovat zjištěné výsledky následovně: zatímco v prvním a druhém období (tj. v letech 2000-2006) nebyly rozdíly v úrovni rychlostních schopností testovaných sprintem na 50 metrů hodnoceny jako statisticky významné, v období 2007-2009 bylo indikováno statisticky významné zlepšení tohoto ukazatele.

V prvním sledovaném období (2000-2003) měla polovina dívek lepší časy než 8,20 s. V letech 20072009 běželo 50 \% žaček sprint na 50 metrů lépe než za 7,81 sekund, přičemž v prvním období nedosáhlo na stejný ani $25 \%$ dívek. V posledním období byl také změřen celkově nejlepší čas v šestých tř́idách za celou dobu testování (2000-2009), a to čas 6,8 sekund. Naopak nejhoršího času dosáhla žačka v roce 2005 (9,3 s). V tomto období (2004-2006) mělo $50 \%$ dívek čas v rozmezí 7,69-8,41 sekund, jak je patrné z obrázku 1. 


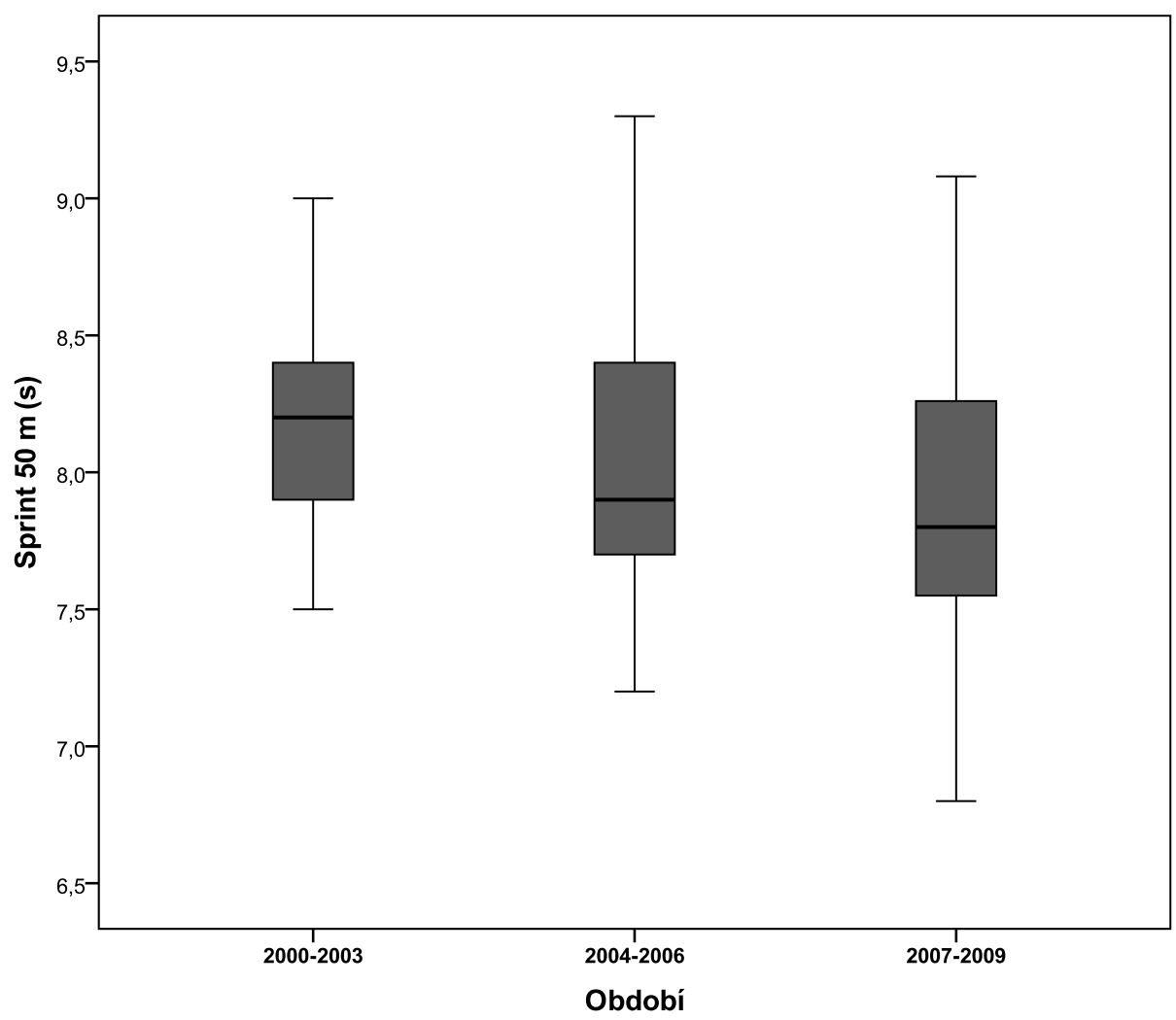

Obrázek 1. Srovnání časů ve sprintu na 50 metrů (dívky z 6. tříd) ve sledovaném období

\section{Diskuse}

$\mathrm{Na} Z \mathrm{~S}$, kde probíhalo měření, se každý rok provádí u všech dětí přijatých do třídy s rozšiřrenou výukou atletiky diagnostika, která charakterizuje jejich vstupní pohybové schopnosti. Toto testování se provádí v rámci dlouhodobého testování všeobecné kondiční připravenosti. Součástí testové baterie všeobecné kondiční připravenosti, kterou uvádí také Perič (2006), je sprint na 50 metrů, který slouží k testování rychlostních schopností. Na základě výsledků Jednofaktorové ANOVY můžeme konstatovat, že v průběhu námi sledovaného období došlo ke statistický významným rozdílům v úrovni rychlostních schopností. Na rozdíl od výsledků u chlapců stejné věkové kategorie $(\mathrm{n}=124)$ uvedených v publikaci Vala, Valová, Litschmannová (2010), kdy nebyly zjištěny statisticky významné rozdíly v úrovni rychlostních schopností ve stejném období (2000-2009), bylo oproti našim předpokladům zjištěno, že u dívek jsou tyto statisticky významné rozdíly pozitivní. Můžeme konstatovat, že v posledním námi sledovaném období byly přijaty dívky s velmi dobrou úrovní rychlostních schopností. To také dokazují výsledky z pozdějšího finále mladšího žactva Moravskoslezského kraje v roce 2007 a 2008, kde dívky ze 6. tříd vyhrály štafetu 4x60 m. Testováním rychlostních schopností se zabývá také řada zahraničních autorů (např. Hoffman, 2006; Mondal, 2006). Námi zjištěné výsledky úrovně rychlostních schopností však nemůžeme porovnat s těmito zahraničními autory, protože používají testy rychlostních schopností na jiné vzdálenosti (30 nebo 50 yardů). Na druhou stranu ale naše výsledky mohou sloužit k porovnání výkonnosti děvčat šestých tříd podobně (sportovně) zaměřených základních škol.

\section{Závěr}

Celkem byly testovány 104 dívky sportovní základní školy, které navštěvovaly v námi sledovaném období (2000-2009) třídy s rozšířenou výukou atletiky. Na základě výše uvedených faktorů jsme očekávali v období 2000-2009 statisticky významné změny v úrovni rychlostních schopností žaček sportov- 
ních tříd. Na základě výsledků ANOVY můžeme konstatovat, že v průběhu námi sledovaných let dochází ke statisticky významné změně střední hodnoty rychlosti u dívek šestých tř́íd ve sprintu na 50 metrů (na hladině významnosti $5 \%$ ). Po provedení Post Hoc analýzy Bonferroniho metodou můžeme konstatovat, že střední časy v testu sprint na 50 metrů si nejsou rovny. V období 2007-2009 bylo indikováno statisticky významné zlepšení tohoto ukazatele oproti období 2000-2006.

\section{Literatura}

ALRICSSON, K.; HARMS-RINGDAHL, K.; WERNER, S. Reliability of sports related functional tests with emphasis on speed and agility in young athletes, Scandinavian Journal of Medicine and Science in Sports, 2001, vol. 11, pp. 229-232.

BAILEY, R.; TAN, J.E.CH.; MORLEY, D. Talented pupils in physical education: secondary school teachers' experiences of identifying talent within the 'Excellence in Cities' scheme, Physical Education and Sport Pedagogy, 2004, vol. 9, no. 2, pp.133-148.

BAILEY, R.; MORLEY, D. Towards a model of talent development in physical education, Sport, Education and Society, 2006, vol. 11, no. 3, pp. 211-230.

BROĎÁNI, J. Vplyv zataženia na zmeny štruktúry výkonu v atletickom šprinte. Nitra, UKF, 2002. ISBN 80-8050-523-3.

BROĎÁNI, J. The Performance in $50 \mathrm{~m}$ Run in Correlation with the Developmment of Speed and Strenght Abilities in Ontogenesis of 11-13 Years Old Students of 8 Years Sport Grammar School in Nitra, Studia Kinanthropologica, 2003, roč. 4, č. 3, s. 17-21. ISSN 1213-2101.

BROĎÁNI, J.; VRÁBCOVÁ, M. Úroveň atletických výberov ŠOG v Nitre v rokoch 1998-2004. In: Soubor referátů z mezinárodního semináře Diagnostika motoriky mládeže. Ostrava: OU PdF v Ostravě, 2006, s. 80-84.

BUKOVÁ, A.; GAJDOŠOVÁ, B. Rýchlost' reakcie 17 a 20-ročnej populácie a rozdiely medzi nimi. In Optimalizácia zataženia v telesnej a športovej výchove SjF STU. Bratislava, 2008, s. 21-25. ISBN 978-80-227-2991-8.

DOVALIL, J., et al. Výkon a trénink ve sportu. 1. vyd. Praha: Olympia, 2002, ISBN 80-7033-760-5.

DOVALIL, J. et al. Lexikon sportovního tréninku. Praha: Karolinum, 2008. ISBN 978-80-246-1404-5.

DOVALIL, J. et al. Výkon a trénink ve sportu. Praha: Olympia, 2009. ISBN 978-80-7376-130-1.

HOFFMAN, J. Norms for Fitness, Performance, and Health, Champaign: Human Kinetics, 2006.

HUTTON, J.; TWIST, P. Training athletic talent, Fitness traper Canada, 2006, pp. 42-44.

CHOVANOVÁ, E. Vplyv netradičných pohybových hier a cvičení na rozvoj reakčnej schopnosti 7-10 ročných detí. Acta Facultatis exercitations corporis Universitatis Presoviensis. Prešov, 2009, roč. 3, č. 3, s. 32-37. ISSN 1732-7156.

MĚKOTA, K.; BLAHUŠ, P. Motorické testy v tělesné výchově. Praha: SNP, 1983

MONDAL, A.. Physical and Motor Fitness Level of Indian (Bengalee) School Going Girls, International Journal of Applied Sports Science, 2006, vol. 18, no. 2, pp. 50-64.

MORAVEC, R.; ŠELINGEROVÁ, M. Vývoj a možnosti prognózovania pohybovej výkonnosti 10-14 ročných žiakov športovej školy so zameraním na atletiku. Teor. Praxe Těl. Vých., 1990, roč., 30, č.11, s. 665-675. PAJTINKA, L. Vzdělávanie športom. In M. Modrák, (ed.) Zimná kalokagatia 2007 (Kalokagatia je ešte aj dnes pre mládež ideál...): zborník prác zodbornej konferencie, Prešov, 2007, 17-20.

PERIČ, T. Sportovní príprava dětí. Praha: Grada, 2004. ISBN 80-247-0683-0.

PERIČ, T. Výběr sportovních talentů. Praha, Grada: 2006. ISBN 80-247-1827-8.

PETERNELJ, B.; ŠKOF, B.; STREL, J. Academic achievement of pupils in sport classes: pupils attending sport classes have higher final grades, but..., Kinesiologia Slovenica, 2009, vol. 15, no. 1, pp. 5-16.

RUBICKÁ, J.; LENKOVÁ, R. Ako na kondiciu a zdatnost'. In Vzlet: časopis Sokola na Slovensku, člena Svetového zväzu sokolstva, 1999, roč. 7, č. 3, s.2-3.

RUŽBARSKÁ, I., TUREK, M. Kondičné a koordinačné schopnosti v motorike detí predškolského a mladšieho školského veku. Prešov: Prešovská univerzita v Prešově fakulta športu, 2007. ISBN 978-80-8068-670-3. 
RYBA, J.; DLOUHÝ, M. Př́spěvek k vývoji talentované mládeže s intenzivnějším pohybovým režimem. In Optimální působení tělesné zátěže a výživy: sborník príspěvkư ze XIV. ročníku interdisciplinární konference s mezinárodní účastí, Hradec Králové, 2007, s. 75-84.

RYCHTECKÝ, A.; FIALOVÁ, L. Didaktika školní tělesné výchovy. Praha: Karolinum, 1998. ISBN 80-7184-659-7.

TRANCKLE, P.; CUSHION, C.J. Rethinking Giftedness and Talent in Sport, Quest, 2006, 58, pp. 256-282. VALA, R.; VALOVÁ, M.; LITSCHMANNOVÁ, M. Úroveň rychlostních schopností žákủ šestých tříd na základní škole s rozšířenou tělesnou výchovou. Studia Kinanthropologica. 2010, roč. 11, č. 1, s. 30-34. ISSN 1213-2101.

VALOVÁ, M.; VALA, R.. Úroveň rychlostních schopností žáků 5. tříd základní školy s rozšířenou výukou tělesné výchovy. In I. Čilík, M. Pupiš, J. Kremnický (eds.): Atletika 2009 - medzinárodný recenzovaný vedeckýzborník, Banská Bystrica, 2009, s. 239-244.

VINDUŠKOVÁ, J., et al.. Abeceda atletického trenéra. 1.vyd. Praha: Olympia, 2003. ISBN 80-7030-770-2.

VINDUŠKOVÁ, J.; KRÁTKÝ, P. Výkonnost žáků v atletických sportovních třídách. In Atletika 2001: Zborník z medzinárodnej konferencie, Banská Bystrica, 2001, s. 146-151.

VOLVER, A.; VIRU, M.; VIRU, K. Formation of sprinting ability in girl, Acta Academiae Olympiquae Estoniae, 2005, vol. 13, no. 2, pp. 11-15.

Internet Sources

Český statistický úřad. Vybrané demografické údaje v České republice. Poslední úpravy 5.1.2011 [cit. 18.1.2011]. Dostupné na www: <http://www.czso.cz/cz/cr_1989_ts/0101.pdf> 